\title{
A kommunista oktatáspolitika a II. világháború utáni években a kettéhasított Európában
}

\author{
SÁSKA GÉZA \\ ELTE PPK
}

\begin{abstract}
A háború után Európában két eltérő társadalmi-politikai rendszer létrejöttével két eltérő ideológiai elveken nyugvó oktatáspolitika szemlélet vált uralkodóvá. Míg Európa nyugati felében a nemzetiszocialista és fasiszta rezsimek megszúnése után visszaállt a demokratikus állam korábbi fenntartói pluralizmusa, addig a szovjet típusú rendszer legfőbb célkitűzése, a felnövekedő generációk fölötti totális kontrol szervezeti feltételeinek kialakítása volt. A tanulmány hidegháború időszakában a szovjet befolyásolási övezetben is egyeduralkodóvá váló kommunista oktatáspolitika jellemzőinek elemző bemutatására tesz kísérletet.
\end{abstract}

Kulcsszavak: kommunista oktatáspolitika, hidegháború, totális diktatúra, központosított iskolarendszer, egységes általános iskola

Európa keleti és nyugati félben különböző úton indultak el a háború után, noha formálisan mindkettő demokratikusnak nevezte önmagát az 1945 februári jaltai konferencia felhívását követve. Churchill, Roosevelt és Sztálin közös elhatározása szerint a legyőzött ellenséges totalitárius és tekintélyelvú országok belső intézményes és ideológiai viszonyait demokratikus rend szerint fogják átalakítani. Ma már nem kétséges, hogy legyőzött országok demokratikus berendezkedésének két, egymástól eltérő formáját és módját építettek fel az egymással szembeforduló hajdani szövetségesek. Míg Európa Nyugati felén a háborúban vesztes országok a totalitárius rendszerüket felváltó polgári demokratikus állam és társadalom újraépítés célját tûzték ki, addig a Szovjetunió a saját befolyási övezetében olyan viszonyok kialakítására törekedett, amelyek alaki tekintetben még éppen hogy megfeleltek a Jaltában leszögezett demokratikus elveknek, de amelyeket a szabad politikai választás, a politikai szabadságok és a képviselet elvei helyett a szovjet birodalmi-biztonsági érdekek irányítottak (Rainer M. és Lux, 2000). A demokráciával és a népek szuverenitásával kapcsolatos sztálini ígéretek semmivé foszlottak (Tarján, 2017). A későbbiekben - mint látni fogjuk a folyamatosan hangoztatott jaltai szavakat jelentő „demokratikus" átalakulás és az ennek ellentétét mutató gyakorlat azonos érvrendszerbe helyezése tetemes gondot okozott koherens agitációs propaganda felépítésében, amit végül a „Népi Demokrácia" formulában találtak meg. 
A nyugat európai és szovjet típusú demokrácia felépítésében lévő különbség az oktatási rendszer reformjában is megmutatkozik. Európa keleti felén az oktatás központosított lett. Az egyházi és a magániskolák államosításával az iskolák, azaz a felnövekvő generációk fölötti totális kontrol kiépítésének szervezeti feltétele jött létre. A szocializmus társadalmi egyenlőség (demokrácia) ígéretét mindenütt olyképpen valósították meg, hogy megtörjék, a kor szófordulatával élve az uralkodó osztályok kulturális monopóliumát az egységes, nyolc évfolyamos egységes oktatással, amelyet később, 1948 után az általános osztályharc egyik eszközeként a felsőfokú továbbtanulás lehetőségét felvételi vizsgák rendszeréhez kötötték, ${ }^{1}$ amelyhez a származás szerinti szelekció lehetősége nyílt meg (Nagy, 2006). Mindezzel egyidőben az esti és levelező tagozatok útján a bukott rendszer kulturális monopóliumainak az áldozatainak tekintett tömegével kaptak mindegyik iskolafokozat végén bizonyítványt, s leendő, vagy kinevezett vezetők általában rövidített úton - szakérettségivel, levelező tagozaton szerezhettek általános iskolai végzettséget, érettségit, illetve egyetemi diplomát nemcsak Magyarországon (Ábent, 1965. 302-303. o.; Sáska, 1992), hanem egységesen valamennyi szovjet befolyás alatt álló országban, így Bulgáriában (Ábent, 1965. 90-92. o.), Csehszlovákiában (Ábent, 1995. 166-168. o.), Lengyelországban (Ábent, 1995. 237-239. o.), az NDK-ban (Ábent, 1995. 381-383. o.), és végül Romániában is (Ábent, 1995. 447-449. o.).

Európa nyugati felén az efféle dolgok nem estek meg a háború utáni években, ott továbbra is fennmaradt a háború, illetve a nemzetiszocializmus, a fasizmus előtti fenntartói pluralizmus, a társadalmi egyenlőtlenség csökkentése érdekében sehol sem jártak el a középosztállyal szemben. A társadalom átalakításának programja teret sehol sem nyert, noha a kommunista pártok, már, ahol voltak szorgalmazták.

Különböző szakmai fórumokon² többnyire szóban elhangzó vélemények szerint azonban nem kelet európai specifikum a szovjet szférában bekövetkezett változások. Szerintük a szelekció pontjának felemelését a különösebben nem részletezett, a II. világháború utáni világtrend kényszerítette ki, s nem a helyi (a nemzeti) kommunista pártok politikája alakította ki. Kétségbe vonják, hogy a szovjet politikának alávett területeken nem egy (moszkvai) központból koordinálták a kommunista pártok oktatás politikáját (is), hanem az országhatárokat átlépő, valamiféle közös alapú értékrend általános elfogadottsága a fő magyarázó elve a fordulatnak. Következésképpen tagadják, hogy eltérő konszolidációs politikát folytatott a Szovjetunió és vele szemben álló Amerikai Egyesült Államok, Franciaország, Anglia a nemzetiszocialista uralom alól az általuk felszabadított területeken. Ezáltal a hivatkozott vélemények képviselői jelentéktelen mozzanatnak tartják, hogy az elsőnek említett szovjet-szocialista

\footnotetext{
${ }^{1}$ A zsidók felsőfokú továbbtanulását korlátozó numerus clausust a második világháború után mindenütt eltörölték. A nyugat európai államok közül egyedül Franciaországban volt felsőfokú vizsga, amelyet az Alkotmánybíróság 1991-ben megtiltott (Hobsbawm, 1998. 284. o.).

2 ld. az egyetlen dokumentumot: https://archive.org/details/Kelemen80, 2017.12.02.
} 
jellegû, egypártrendszerú, totalitárius rendszer építésébe kezdett, a másodikként pedig a fékek és ellensúlyokon alapuló, - több párt rendszerú - polgári demokratikuséba.

Az oktatási rendszer - szerintük - mindenütt demokratizálódott Európában, azonban a totalitárius berendezkedésứ országban jóval demokratikusabb, mert az iskolarendszerük nagyobb egyelőséget teremtett, hiszen a formális szelekció pontja a polgári demokratikus úton járó országokhoz képest magasabb életkorra tolódott ki.

Éppen ezért kell feltárnunk a neveléstudomány múvelői előtt, a háború után induló a két, egymást nem keresztező, egymásba sohasem nyíló szovjet típusú népi- és a nyugat európai polgári demokratikus út különbségét már, ami az iskolarendszer szerkezetében és az oktatáspolitika jellegében mutatkozik. Mindehhez a keletkezésük történetének vizsgálata a kézenfekvő.

\section{A KELET EURÓPAI KOMMUNISTA OKTÁSPOLITIKA}

Az iskolarendszer átszabását a szocializmus alapeszméjét, az egyenlőséget meghozó forradalomnak tekintették a szocializmust építő népi demokratikus Magyarországon is, amely a demokrácia ismert hármas jelszavából csak ezt az egyet emelték ki, azonban a „szabadságot” a "testvériséget”, azaz a szerveződés [liberalizmus], az egyesületi, a nemzeti közösségi élet [nacionalizmus] jogát elvették. Összehasonlításképpen a nyugat európai polgári demokratikus országokban az 1945 utáni oktatási reformoknak sehol sem volt forradalmi jellege. A tiltakozás jogát és az egyesülés szabadságát sehol sem korlátozták. Mindenütt fennmaradt az iskolafenntartás pluralizmusa - a nem állami iskolák rendszere, amelynek a világnézeti politikai közömbösség a feltétele és az alacsonyabb szintû egyenlőtlenség a következménye.

Magyarországon az általános iskola megteremtését a rendszerváltásig a kommunisták sikerének, rendszerük legitimációs alapjának tekintették, amelyet kezdetben szocialista, majd demokratikus forradalomnak nevezték. Vélhetően agitációs propaganda szülötte e két szó használata: a társadalmi egyenlőség rendkívül gyors, az egyik napról a másikra történő megvalósulására utal a forradalmi jelző.

Nemes Dezső, a párt keményvonalas ideológusa fogalmazásában a Magyar Kommunista Párt (MKP) már 1945-ben a társadalmi átalakítás élére állt, ami ekkor már "tartalmazza... a szocialista forradalomnak. . . igen lényeges elemeit" (S. G. kiemelése) (Nemes, 1960. 233. o.). Az általános iskola e forradalom gyümölcse.

A „szocialista forradalom” fogalma metafora csupán, hiszen 1945-ben az MKP, mint mindegyik európai kommunista párt Sztálin intenciói szerint a választási győzelemmel akart kormányra kerülni, és nem forradalommal, ahogy ez a megszállt országokon kívül Francia-, és Olaszországban sikerült is (Mueller, 2006). Más szemszögből ugyanaz: a háború végeztével Sztálin nem támogatja a 
teljes kommunista hatalomátvételt Magyarországon, de ragaszkodik ahhoz, hogy a helyi kommunista pártok kulcspozíciókat szerezzenek a politikai hatalomban (Szabó, 2014; Rainer M. és Lux, 2000). Az általános iskola kikényszerítése Magyarországon kétségtelenül forradalmi tett volt, amire mégis egyfajta puccsként lehet tekinteni a parlamenti polgári liberális felfogás szerint . Hiszen a reformot nem törvény, hanem rendelet útján ${ }^{3}$ indította el az az Ideiglenes Kormány, amelyik köztudottan nem választások révén állt fel, hanem a szovjet csapatok előre nyomulása következtében keletkezett hatalmi ûrben és a szovjetek ellenőrzése alatt vette át - mint a neve is jelzi ideiglenesen - az ország irányítását.

A neveléstudomány későbbi vezető képviselői munkáikban nem érzékelték a demokratikus és a forradalmi viszonyok közötti különbséget, a célok felől közeledve indokoltnak látták az iskolarendszer átalakításának kikényszerítését. ${ }^{4}$ Ábent Ferenc 1962-ben a kor jellegzetes álláspontját képviselte. A Szovjetunióban kandidált szerzo úgy látja, hogy „A közoktatás új rendszere legnagyobbrészt a Magyar Kommunista Pártnak köszönhetö. . a nyolcosztályos, minden gyermek számára kötelezö általános iskola életre hívása forradalmi cselekedet volt." (S.G. kiemelései) (Ábent, 1965. 263. o. $)^{5}$ Lényegében ugyanezt állítja az ötvenes évek oktatáspolitikájának meghatározó személye, a miniszterhelyettes Jóború Magda is: „Az ideiglenes Kormány a Magyar Kommunista Párt javaslatára (S.G. kiemelése) 1945. augusztus 16-án rendeletileg kimondta az általános iskola létrehozását." (Jóború, 1961. 50. o.)

A néptanítói iskolázottságú és ethoszú oktatáspolitikus, neveléstörténész Simon Gyula 1965-ben íródott és 1970-ben nyomtatásban megismételt sorai szerint az 1945-ös „,... ] forradalmi demokratikus (S. G. kiemelése) átalakulásnak a Magyar Kommunista Párt volt a vezetö ereje." (Simon, 1965. 15-18. o.; Simon, 1970. 216. o.). Azaz: az egyenlőség forradalmi eszközökkel történő kikényszerítése demokratikus: nem az eszköznek, hanem a célnak van legitimáló jelentősége.

Ugyanebben az értelemben használja a demokrácia fogalmát két vezető pártszakértő 1966-ban. Az általános iskola létrejöttének idejét „munkás-paraszt demokratikus diktatúra" (S.G. kiemelése) időszakára teszi, az értelmezésükben a szocialista iskola megteremtése csak a fordulat éve után kerül sor (Kornidesz-

\footnotetext{
${ }^{3}$ A tekintélyelvú politikai berendezkedés is élt a törvényi szintû szabályozás megkerülés eszközével. Hóman Bálint, az általa beterjesztetett 1934. évi a középiskoláról szóló törvény elfogadása mellett többek között azzal is érvelt, hogy az 1924. évi középiskolai törvényt időközben rendeletekkel többször módosították, s márpedig az ő 1934-es törvényjavaslata az a szabályozási gyakorlatból keletkező káoszt számolná fel (Jóború, 1963. 24. o.).

${ }^{4} \mathrm{Az}$ általános iskola történetét pedagógus kultúrájú személyek írták, akik főként e nézőpontból tekintettek az eseményekre. A politológiai szempontú elemzés nem született, ha az apologetikát nem vesszük tekintetbe. Ezzel magyarázható, hogy a ,jó szakmai törekvések és a rossz politikai döntések” logikája szerint íródott a történet. (Ld. Horváth, 1978; Kardos, 2007)

${ }^{5} \mathrm{Az}$ idézet első forrása Das schulwesen sozialisticher lander In Europa. Volk and Wissen Volkgseigener Verlag, Berlin, 1962 amelynek magyar fejezetét a Pedagógiai Tudományos Intézetének munkatársai írták. A jelentős forrásértékú kiadványban valamennyi szovjet befolyás alatt álló szocialista-kommunista ország oktatásügyét bemutatják az intézményes neveléstudomány képviselői.
} 
Kurucz, 1966. 13.). Szerintük a diktatúra is lehet demokratikus. A hatvanas évek máig élő ideológiája szerint nem az állam diktatórikus vagy demokratikus berendezkedése a fontos, hanem a megteremtett egyenlőség foka. Másképpen: az egyenlőség igénylése mindkét politikai berendezkedést egyaránt legitimálja. ${ }^{6}$

A demokratikus társadalom egyenlősége és a politikai berendezkedés közötti megkülönböztetés elmaradása folyamatos ideológiai bizonytalanságot teremtett. Az V. Nevelésügyi Kongresszuson, 1970-ben a sztálinista alapokhoz visszanyúló vezérszónok, Péter Ernő a Pedagógus Szakszervezetének az elnöke szerint a felszabadulás után „Közoktatáspolitikai törekvéseink először a demokratikus, majd a szocialista (S. G. kiemelése) iskola létrehívására irányultak. (Péter, 1971. 15. o.). A kommunista közoktatáspolitika két szakaszáról van szó.

\section{MosZKOVITÁK MINDENÜTT?}

Ahogy a szovjet Vörös Hadsereg haladt Nyugat-Európa felé, nyomukban vagy velük együtt jöttek meg az évek óta a szovjet emigrációban élő kommunista politikusok, és együtt érkeztek nem ritkán szovjet katonai egyenruhát viselve azok is akik (többnyire munkaszolgálatosként) a szovjet oldalra átszöktek mint például Mérei Ferenc. E jól szervezett kommunista csoport tagjait és ideológiájukat osztó, velük együttmúködő, korábban ellenzéki szerepben lévő személyeket, $^{7}$ nevezte - részben igaztalanul ${ }^{8}$ - a Vallás és Közoktatásügyi Minisztérium 1945-46-os államtitkára Bassola Zoltán is moszkovitáknak.

Valamennyi kelet európai országban ugyanez történt, mindenütt volt Moszkva politikáját követő, a hatalom megszerzésére szerveződött honiak, és a katonai előrenyomulással érkező kommunisták csoportja. A háború utáni ideiglenes, valamint első többnyire szabad választások eredménye alapján felálló kormányokban kulcsszerepet játszottak a kommunisták (Applebaum, 2012. 49. o.).

Csehszlovákiában a Müncheni Egyezményt követően, 1938 óta a Szovjetunióban élő és politikai szerepet betöltő Klement Gottwald 1945-ben a csehszlovák ideiglenes kormányban a második ember, 1946-ban már az első: miniszterelnök.

Jugoszláviában a harmincas évektől a Szovjetunióban elő, Komintern munkatárs, a győztes partizán vezér, Josip Broz Tito 1939-től a jugoszláv kommunista párt első titkára. Választásokat csak a háborús kormányalakítás után

\footnotetext{
${ }^{6}$ E kettősség tisztázása elmarad a tekintélyelvú vagy totalitárius rendszerek bukását követő időszakban, a társadalmi egyenlőség képviselete erőssége általában erősebb a demokrácia felépítésénél, védelménél, mert a demokratikus berendezkedésú politikai rendszerről nincs közvetlen tapasztalat, de az egyenlőtlenség tényéről mindig van.

7 Azokra gondolt „akiknek idegenből visszatért elvtársai adták át a künn szerzett ideológiai tudást, s akiket ők részesítettek pártvezetésre és vezetésre vonatkozó kiképzésre." (Bassola, 1998. 363. o.)

${ }^{8}$ Bassola nézőpontjából egyforma minden kommunista, vagy feléjük forduló szociáldemokrata. Nagy különbség van azonban közöttük is, elég, ha a magyarországiak közül Kemény Ferenc és Ágoston Györgyre, vagy a Szovjetunióból érkezettek közül Mérei Ferencre és Andics Erzsébetre gondolunk. Arról nem is szólva, hogy 1948 előtt és után a politikai üldözés célpontjaivá váltak a hazai baloldal képviselői is, többek között Kéthly Anna, Rajk és Szakasits, Szeder Ferenc, Demény Pál, Weishaus Aladár.
} 
tartott.(Sztálinnal való szakítás előtt a jugoszláv oktatáspolitika szorosan követte a szovjet utat - többek között a 7 osztályos egysége általános iskola felállítása (Skubić, Spacenović, Vuisić-Živković, Vrcelj és Popov, 2013), 1948 után azonban önálló utat járt be, s ezért a szovjet típusútól eltérő oktatáspolitikájára itt nem térhetünk ki.)

Bulgáriában a kommunista vezető, Georgi Dimitrov 1924 óta élt a Szovjetunióban, a szovjet hadsereggel tért vissza 1944-ben, s nyomban a Kommunista párt vezetője lett. 1946-ben a kommunisták vezette Hazafias Front miniszterelnöknek nevezte ki, - választást nem tartottak - s megteremtve az egy-párt rendszerú szovjet rendszerú szocialista állam felépítésének lehetőségét.

Hazai kommunista csupán Romániában Gheorge Gheorgiu-Des lett 1945-töl a kommunista párt elnöke, és a kormány, a gazdasági tervezésért felelős tagja volt.

Magyarországon és Lengyelországban pár évvel később kerültek hatalomba a Moszkvából érkezett magyar és lengyel kommunisták, befolyásuk azonban előtte is jelentősnek mondható. Az osztrák kommunisták előtt nem nyílt ilyen lehetőség.

Nyugat Európában két Szovjetunióból érkezett kommunista vezető jutott végrehajtó hatalomhoz. Franciaországban a kommunista vezetőnek a MolotovRibbentrop paktum fegyelmezett támogatása miatt elvették állampolgárságát. Maurice Thorez ezek után 1943-tól a háborús éveket a Szovjetunióban töltötte. Majd a háború után, de Gaulle visszahívta, s vezetésével az 1945-ben megtartott választáson a Kommunista Párt győzött, a szavazatok 25\%-t megszerezve, Thorez miniszterelnök helyettese lett 1947 májusáig.

Olaszországban - számúzött, 1930-tól szovjet állampolgár - az Olasz Kommunista Párt vezetője, Palmiro Togliatti, töltött be 1944 és 1948 között kormányzati szerepet tárca nélküli miniszterként 1947-ig, az 1948-as választások eredménye után mindvégig a kommunista ellenzék élén állott.

Az ötvenes évek elején kortárs Hannah Arrend úgy látta, hogy a „Moszkva által dominált kelet európai kormányok Moszkva érdekében uralkodnak és Kominternügynökként cselekszenek. Ezek nem mások, mint Moszkva által irányított totalitárius mozgalom terjeszkedésének példái, és nem belső fejlödés következményei" (S.G. kiemelése) (Arendt, 1992. 414. o.).

\section{A MOSZKVAI EREDETÚ OKTATÁSPOLITIKA TÁMASZAI}

A Keletről érkezettek köréből kerültek ki azok, akiknek meggyőződésükből fakadt, vagy pártfeladatuk volt az egységes alapfokú oktatás megteremtése. A tanítóság gimnázium ellenességére, a középosztállyal, ami ugyanaz a gimnáziumi tanársággal szembeni irigységgel elegyes ellenszenvére építkeztek. Azokért politizáltak, akiket vonzott a felemelkedés, a nagyobb tekintély, magasabb élet- 
színvonal ígérete, s a maguk értékei általánossá tételének vágya és lehetősége. ${ }^{9}$ Voltaképpen az osztályharc politika egyfajta erre a tartós resszentimentre építkezett. ${ }^{10}$ (A kommunista politikai antiszemitizmusára és az általános iskolát szakmailag megteremtő, a háború előtti magyar faj védelmében fellépő jeles pedagógusokkal kötött szövetségre itt nem térhetünk ki (ld. Sáska, 2016.)

Kiss Árpádnak ${ }^{11}$ ugyanez a tapasztalata a tanítósággal, 1947-ben: "Az általános iskolának ma a tanitóság a legmeggyőződésesebb és legmaróbban hadakozó híve. Elméleti és közösségi szempontokon kivü̈l természetesen az eddigi rendi sérelmek is hajtják egy magasabb minősités, nagyobb megbecsülés, társadalmi elismerés felé" (Kiss, 1947). A közösséghez tartozás érzésére és a resszentimentre-re bármelyik politikai oldalról, ${ }^{12}$ bármikor lehetett politikát építeni.

Az ötvenes évek szovjet oktatási miniszter helyettese előtt is ismert volt ez a politikai eszköz. Pontosan leírta azt a taktikát, amellyel a kommunista pártok a tanítóságot hatalom megszerzésének eszközeként felhasználhatják: „,a munkásosztály és politikai pártjai már a kapitalizmusban szövetségesüknek tekintették a néptanítót (S. G. kiemelése), támogatták az iskola fejlesztésért ${ }^{13}$ folytatott harcát, és arra törekedtek, hogy bevonják őt a kapitalista társadalom elleni harcba." (Arszenyev, 1965. 29. o.).

A forgatókönyv létének ${ }^{14}$ lényeges bizonyítéka az, hogy az ötvenes évek

\footnotetext{
${ }^{9}$ Az állami oktatási rendszer alulról építkező ága a népoktatás, a másik az egyetemből lefelé nyúló gimnázium. E két terület pedagógusai minden tekintetben különböznek, származásuk, házastársuk, a társadalomképük, a fogyasztott és épített kultúrájuk. A pedagógia felfogásuk és különböző és ez a különbség mind a mai napig él, így a két tábor küzd egymással (Sáska, 2015).

${ }^{10}$ A néptanítók szervezetei, már 1896 követelték az egyenrangúságukat a gimnáziumi tanársággal. Ez volt az egyik motívuma a tanítóképzés felsőfokú szintre emelésének, és útja a vele járó jövedelem eléréséhez. Ehhez a politikához kapcsolódott a 8 osztályos népiskola felállításának követelése 1910-ben (Donáth, 2015. 256-259. o.; Kelemen, 1993. 24.). o.

${ }^{11}$ Kiss Árpád szakmai-politikai pályájának három szakasza közül az első, a fajvédő-pedagógus feledésbe merült, az 1945-1948 között, az elbukott demokratikus kísérlet egyik szakma-politikai szereplőjének maradt meg, illetve, s ez a harmadik, internálást követően a posztsztálini rendszerrel zökkenőmentesen együttmúködő jó minőségú, Nyugat-Európára nyitott képviselőjének képe élt tovább.

12 A néptanítók radikalizmusára Magyarországon Gömbös politikája és későbbi a nyilas mozgalom is épített.

13 E politikusi szavak világossá teszik a pedagógiai-szakmai koncepciók politikai jellegét és értékét. 1945-ben a tanítóság évtizedes követelése teljesült: létrejött és teljes egészében a tanítóké lett az egységes nyolc osztályos általános iskola és megszúnt a középfokú tanítóképzés - egy időre. A felsőfokú a Pedagógiai Főiskolán az alsó és a felső tagozati oktatásra egyaránt felkészítették a tanítókat (Ladányi, 1989. 36. o.). Végül is, amint a kapitalizmus elleni harc gyózelemmel zárult, a tanítóknak tett politikai ígéretekből nem lett semmi, hasonlóan az önálló gazdálkodásból és a földosztásból a parasztság esetében. Amit adtak a tanítóságnak, el is vették 1949-ben: a felsőfokú képzést, és az általános iskola felső tagozatát. Visszaállították a középfokú tanítóképzést, a Pedagógiai Főiskolákon csak a felső tagozat tanárait képezték. Szaktanítóként a felső tagozaton lehetett dolgozni a szaktanfolyam sikeres elvégzését követően. A tanítók munkaterhei továbbra is nagy volt, jövedelmük viszont alacsonyabb lett, mint a Pedagógusképzőt végzett kollégáké. A középfokon dolgozó tanárokhoz képest relatív előnyük noha csökkent, de továbbra is fennmaradt. Ezek után mindkettőjükkel szembeni tanítói resszentiment érzése állandósult.

14 Tudható, hogy a szovjet befolyás erős volt a negyvenes és ötvenes években. A mechanizmusuk
} 
legvégén, bő tíz évvel a kelet európai kommunista hatalomátvétel után az előbb idézett szovjet politikus-neveléstudós győztesként leszögezte: „Az egységes iskola elve megköveteli, hogy a legmagasabb képzettséget minden tanuló elérhesse ${ }^{15}[. .$. Egyik iskola sem lehet " zsákutca "16 amely [a] végzett növendékei számára nem ad lehetóséget a továbbtanulásra. Az egységes iskolának ezek az alapelvei a szocialista országokban már megvalósultak" (S. G. kiemelése) (Arszenyev, 1965. 29.), tehát mindegyikben.

A szovjet érdekszférába tartozó valamennyi európai országban létrehozták az általános és egységes iskolát már a negyvenes években (Faragó-Kiss, 1949. 262-263. o.), amelyekben a háború előtti iskolaszerkezethez képest hosszabb ideig kell mindegyik társadalmi rétegbe tartozó gyereknek kötelező ugyanazt együtt tanulni. A tartalmi egységesség szervezeti kereteit az ISCED rendszerben kifejezve az alsó középiskola egységesítésével érték el, valamint az iskolák fölötti állami kontrolt az iskolafenntartók államosításával megerősítették, nincs már magániskola, illetve egyházi fenntartású iskolarendszer sem. 1950-ig mindenütt államosították az ilyen típusú intézményeket, országonként eltérő ütemben.

\section{Az EGYSÉGES ÉS ÁLTALÁNOS KÉPZÉS MEGTEREMTÉSE A SZOVJET ÉRDEKSZFÉRÁBA TARTOZÓ KELET EURÓPAI ORSZÁGOKBAN}

Csehszlovákiában, - ahogy a neveléstudomány akkori szakemberei később megfogalmazták - „,a reakció ellenállása miatt”, a kommunisták csak 1948-ban tudták elfogadtatni az egységes közoktatás szabályozásáról szóló törvényt a „Törvény az egységes iskoláról" a 9 éves általános képzést ingyenesnek és kötelezőnek nyilvánította minden 6-15 éves gyermek számára függetlenül nemétől, nemzetiségétől, vallásától, és szüleinek társadalmi és anyagi helyzetétől. Az iskolát elválasztották az egyháztól (Kaszvin és Sibanov, 1959. 124. o.). A döntő lépést azonban három évvel korábban már megtették. „1945 novemberében az általánosan képző iskolák részére új tantervet adtak ki [...]. Ennek a feladata volt az is, hogy elökészítse (S. G. kiemelése) a középiskolák (gimnáziumok, reálgimnáziumok, reáliskolák) alsó négy osztályának a polgári iskolával való összeolvasztását." 1948 őszétől hozzák létre az általános iskolát, az iskolák államosításával egy időben. „Ez a törvény megszüntette az oktatási rendszer kettôsségét és megteremtette az egységes állami iskolát" (Dyma és Kozjar, 1965. 118. o.) Az államosítással teljessé vált az oktatási rendszer irányításának egysége.

azonban nem ismert, mint ahogy az sem, hogy miben volt az utasítás teljesítése és miben az eszme-követő magatartás. Ismert, hogy a SZKP vezetőinek politikáját szorosan követte a szocialista országok többsége. Lásd a hruscsovi 1958-ban kezdődő reformról (Faragó, 1959b) és hatásáról (Jóború, 1962, Sáska, 1981). A korábbi időszakokról: Sáska, 2009; Kalmár, 2014.

15 A Kontextus kedvéért idézem a kihagyott mondatot "Az egyes iskolafokozatok tanterveinek ennek következtében lépcsőzetesen egymásra kell épülniük.” (Arszenyev, 1965. 29. o.) A miniszterhelyettes a tantervi szabályozás lényegére mutatott rá.

${ }^{16}$ Közismert, hogy a mobilitás politikai ígérete a „zsákutca” megszüntetése. 
Lengyelország esete az előbbitől némileg különbözik. A háború utáni oktatáspolitika a német megszállás előtti, az 1932-es reform alapján szerveződő $6+4+2$ rendszerú iskolarendszerhez ${ }^{17}$ nyúlt vissza, amelyet a fasiszta megszállás képzés-minimalizálási politikája teljesen elsöpört. 1946-ban hozták létre az egységes hét osztályos általános iskolát Piłsudski 1932 hat osztályos népiskolájából olyképpen, hogy a korábbi négy osztályos gimnáziumból egy évfolyamot a népiskolához csatoltak. 1948-ban azonban kiiktattattak a gimnáziumokat, olyképpen, hogy a líceumi képzést egy évvel meghosszabbították. A hétosztályos általános iskola és négyéves líceumi 7+4-es rendszere jött létre. Az érettségi megszerzéséhez szükséges képzési idő hossza egy évvel ugyan rövidebb lett, de „[...] ezáltal megszúnt az oktatás több fokozatú jellege, ugyanakkor az ifjúság szélesebb köre számára vált lehetövé, hogy megszerezze az érettségit, és ezáltal a föiskolai tanulmányokhoz való jogot." (Pecherski, 1965. 192. o.) Ez a múvelődési egyenlőség megteremtésének módja egy zsákutca nélküli rendszerben: rövidül a képzés és megszüntetnek egy szelektáló képzési formát.

Bulgáriában is a Csehszlovákhoz és Lengyelországhoz sokban hasonló módon, ha úgy tetszik forgatókönyv szerint alakultak az események, noha alapvetően mások voltak a feltételek, de azonosak a politikai körülmények. A háború előtti négy osztályos népiskola és hároméves „pro-gimnázium” alkotta a képzés alsó szakaszát. A hetedik évfolyam után indult az egyik irányba „zsákutcás” ág, a 3 éves reáliskola, amelyet 1944 után szüntetettek meg. A felsőbb tanulmányokra felkészítő ág, erősen szelektív, 5 éves gimnáziumi képzés volt (Csakarov és $m$ tsai, 1965. 53. o.). A rendszer zsákutcás ága tíz [(4+3)+3], a felsőfokra vezető ág pedig tizenkét,[(4+3)+5] éves volt.

A főként külföldiek által fenntartott 5 éves gimnáziumokat államosították, lényegében bezárták (Georgeoff, 1977). 1950-től kezdték kiépíteni a 11 évfolyamból álló 7+3 rendszerû egységes iskolát, amelynek a felső három éve volt a gimnázium (Georgeoff, 1977. 55. o.). A háború előtti gimnáziumi ág hosszához képest az egységes képzés egy tanévvel rövidebb lett, mint Lengyelországban. Az érettségihez Bulgáriában is a rövidebb idő alatt és többen juthattak a fiatalok. Ahogy egy szovjet szerző írja 1958-ban: „Minden polgár szociális származásától, vagyoni helyzetétól, nemzetei hovatartozásától, nemétől és vallásától függetlenül elnyerte a tanulás jogát. Az iskola állami és világi jellegü lett. A közoktatásügyi rendszert az egység és a továbbtanulás biztositása elvének megfelelően újjászervezték, az iskolázást minden polgár számára lehetővé tették" (Kaszvin, 1959. 140. o.).

Romániában a zsákutcát a négy osztályos népoktatást követő, hároméves szakmai előkészítő tanfolyam jelentette, amelyet a kommunista párt győzelmét

\footnotetext{
17 Piłsudski 1932-es reformja megszüntette a porosz eredetû́ magyarországiéhoz hasonló szerkezetú oktatási rendszert, egységes hat osztályos népiskolát teremtett, ahonnan a négy évfolyamos gimnáziumba lehetett tovább tanulni. A reform előtti 8 osztályos gimnázium első felét nevezték 1932 után gimnáziumnak, amelynek elvégzése azonban felsőfokú továbbtanulásra nem jogosított. A 6+4 rendszerú képzés befejezés után kétéves líceumi tanulmányok után lehetett felsőfokú képzésben részt venni. A német megszállás előtt $6+4+2$ rendszer volt kiépülőben, amelyben - úgy tûnik - nem volt „zsákutcás” típus, azonban hierarchikus felépítésû volt és erősen szelektív logikán alapult.
} 
követően, az államosítás évében meg is szüntettek, miképpen a nyolc osztályos gimnáziumot is, létrehozva ezzel a 7 osztályos egységes állami általános iskolát, amelyre a gimnáziumi képzés három éve épült (Stoian és Gabrea, 1965. 405. o.).

A fentiek alapján úgy tûnik, hogy a kelet európai kommunisták a béke első napjaitól kezdve egyazon közös terv egyik elemeként építették fel oktatási politikájukat, s közülük a magyarországiak voltak a legsikeresebbek, még a teljes hatalomátvétel előtt elérték az egységes alapfokú oktatás megteremtését és a zsákutcás képzési rendszer felszámolását, amit a többieknek csak a totális hatalomátvétel után - az államosítással egy füst alatt - sikerült. ${ }^{18} \mathrm{Az}$ államosítás Magyarországon már az első pillanatban megkezdődött. ${ }^{19}$

\section{NÉPI DEMOKRATIKUS FORDULAT KÍSÉRLETE A HÁBORÚ UTÁNI NyUGAT-EURÓPÁbAN}

Érdemes áttekinteni, hogy mi történt az egységes népoktatás megteremtése terén Nyugat Európában a háború után.

Az UNESCO 1956. január 9. és 14. között Hamburgban tartott nemzetközi konferenciáján a kapitalista országok neveléstudósai csupán arról beszéltek, hogy milyennek kellene lennie - tehát a gyakorlat e szerint nem ilyen - a polgári demokratikus országok közoktatás rendszerének. A konferenciakötet bevezető tanulmány szavai szerint, hogy a polgári demokrácia „egyenlőség elve megköveteli, hogy... ne legyen a társadalmi osztályok szerinti megkülönböztetésen alapuló kettős iskolarendszer." (Faragó, 1959a. 20.), amelyben a munkás-, és a középosztály osztály gyermekei különböző képzésben részesülnek, s az esélyek egyenlőtlenek az „az iskola elvégzése után feltáruló jövő színe elött” (U.o.) Mindebből következik, hogy 1945 után az ötvenes évek végéig, a hatvanas évek elejéig a polgári demokratikus utat járó országok ${ }^{20}$ - Svédország részleges kivételével - fenntartották az elitbe kerülés tekintetében funkcionálisan „zsákutcás” oktatási rendszerüket.

A háborúban semleges Svédországban 1932 óta hatalmon lévő szociáldemokrata kormány 1944-ben, más források szerint 1946-ban (Kozma, 1972. 8. o.) kezdte el az iskolarendszer átalakítását célzó reformbizottságát, amely alapján a Parlament majd csak 1950-ben fogadta el a kísérleti 9 osztályos egységes iskoláról

\footnotetext{
${ }^{18}$ Meglehet, hogy a magyar 8+4 rendszer fennmaradása összefügg 8 osztályos népiskola, illetve az egységes és általános nyolc osztályos általános iskola 1945-ös létrehozásával.

19 Az oktatás tartalma fölötti totális állami kontroll első lépéseinek egyike volt az 1946-ban meginduló állami tankönyvkiadás, amit a pedagógiai elit a szakmaiság a piacgazdaság felett aratott győzelmének és a társadalmi egyelőség megteremtése feltételének tekintett (Kiss, 1946). Nyilvánvaló volt, hogy ez az intézkedés az egyházi oktatás mozgásterét erősen szúkíti (Ld. Mészáros, 1989. 89-104. o.). Az is tudható, hogy a középosztály közömbösen fogadta a termelóeszközök folyamatos államosítást, a nem-magyar gyár és üzem tulajdonosok sorsát nem követték, a következményeit pedig nem látták (Szabó, 2014).

20 Az UNESCO 1956-ban tartott konferenciája példaként csupán Norvégiát tudja felhozni, ahol „több mint 30 éve [...] a 7-14 éves gyerekek számára kivétel nélkül bevezették az egységes iskolát." (Faragó, 1959a. 31. о.)
} 
szóló törvényt ${ }^{21}$ (Hegedüs, 1971a). A kísérlet abban állt, hogy továbbra is fennmaradt a hatosztályos elemi negyedik osztályára épülő nyolcosztályos gimnázium, a két párhuzamos szerkezet múködését rendszeresen összehasonlították. Az iskolák fenntartói többnyire a városi önkormányzatok voltak, csekély arányban voltak a magániskolák (Akerman, 1967; Husen-Bolt, 1964). Majd csak 1962-ben vezetik be általánosan a kilencosztályos általános iskolát öt év előkészítő munka után (Kozma, 1972. 8. o.) A szociáldemokrata vagy másképpen fogalmazva demokratikus szocialista ideológiai célja a jóléti állam megteremtése, aminek fontos eleme a társadalmi egyenlőség puha szociálpolitikai eszközökkel történő megteremtése, többek között az iskolai élet szervezésével, az iskolarendszer átalakításával.

A Németország két felét megszálló csapatok különböző (oktatás-) politikát folytattak.

A Német Szövetségi Köztársaságban 1945 után nem volt a szovjet mintára emlékeztető iskolaszerkezet-reform, sőt 1945-ben a Hitler előtti, eredeti, a XIX. századi - zsákutcás - formájában állították vissza az oktatási rendszer szerkezetét (Hegedüs, 1971b). Hitler a közpofokon hajtott végre - itt részleteiben nem tárgyalt - szerkezeti reformokat, a négyosztályos népiskola (Volksschule) hossza változatlanul hagyta, amelyből különböző irányba indultak el az utak. A háború után - mint mindenütt kiirtották a fasiszta és a győzteseket érintő tartalmakat, s nyomban kriminalizálták a 'Deutsche Gemeinschaftsschule'(a Német Közösségi Iskola) nevelési szellemét, amelyet nácik az „Ein Volk, ein Reich, eine Schule” politika jegyében (a bezárt) felekezeti és magán iskolák alternatívájának állították (Glen, 1995. 272. o.). Mindemellett a szövetségesek támogatásával a reformpedagógia német nemzeti tradícióinak felélesztésének kísérletére is sor került. (Németh és Pukánszky, 1996).

A Német Szövetségi Köztársaságban az államélet jogi alapjainak megteremtését követően 1949-ben született meg az „iskolatörvény” (Hilker, 1959. 101-102. o.), nem úgy, mint a szovjet érdekszférában tartozó szocialista, magukat népi demokratikusnak tartó országok többségében, ahol az államjogi kereteinek kialakítása előtt változtattak az oktatási rendszeren. Az ideológiai kontrollt lehetővé tevő központosítás ellenszerét az oktatási ügyekben is autonóm tartormányi nagyobb városok rendszerben találták meg. Annak ellenére, hogy a Szövetséges Ellenőrző Tanács 54. számú irányelvének 4. pontja szerint egységesen két egymásra épülő, a népiskolára alapozódó középiskolai rendszernek kellett volna lennie, azonban az autonóm Bréma, Hamburg, és Nyugat-Berlin városokban 6 osztályos népiskola rendjét vezették be, míg máshol megmaradtak a 4 osztályos elemi mellett. Ennek megfelelően a népiskolai felső tagozatok 4 vagy 3 osztályosok, a középfokú iskolák pedig 8, 6, esetenként 9, vagy 7 osztályosok voltak (Hilker, 1959. 109. o.). Csak 1955-ben annyiban egységesítették a rendszert, hogy 9 vagy 7 osztályos gimnáziumok szervezését engedte meg a hatóság. A

\footnotetext{
21 A 9 osztályos iskolát három tagozatra osztották 1-3; 4-6 és 7-9 évfolyamra. A 9 osztályban három képzési irányt nyitottak, a továbbtanulás előkészítéseként (U. o.)
} 
népiskolák 57\%-a egyházi fenntartásban voltak még 1963-ban is, a középiskolák tanulóinak 10\%-a járt magániskolába ekkor (Hegedüs, 1971b).

Csupán a különbségek könnyebb érzékeltetése kedvéért tárgyaljuk itt Németország keleti felének eseményeit. A szovjet ellenőrzés alatt álló közigazgatási zónába eső német területen már 1946-ben már meghozták a Kelet Német Oktatási törvényt (Glen, 1955. 274. o.). A törvény elötti időszakban alapvetően az egyházi és reformpedagógia ihletettségû́ magán iskolák robbanásszerúen sokasodtak, ahogy az a központosított és államosított oktatási rendszer összeomlása után oly gyakori. Németország keleti felén főleg Kerschensteiner szellemiségú munkaiskolák jöttek létre, amelyek a törvény elfogadása az új, a társadalmi egységességet és szocialista szellemiséget szolgáló 8 osztályos egységes iskolává alakultak vagy megszúntek. Az új oktatási formát a munkás és paraszt származásúak vélt, vagy valóságos érdekére hivatkozva hozták létre, ${ }^{22}$ a középosztály ellenében teremve meg a társadalmi egyenlőséget. A fenntartói pluralitás, mint a demokratizálódás akadálya, a törvény után jelentősen csökken Kelet Németországban (Hofman, 1962). Majd 1951-ben, gyakorlatilag a svédekkel egyidőben hozták létre a 10 osztályos általános iskolát, ami egy évvel hosszabb lett, mint a kapitalista skandináv - talán - vetélytárs. A „demokratikus” iskola elnevezésből „szocialista” iskola lett, voltaképpen e két fogalomnak azonos jelentést tulajdonítottak (Glen, 1955. 52. o.). o A változások élén a német kommunista párt állt hasonlóképpen, mint Magyarországon, vagy a szovjet blokk országaiban.

Ami pedig az angol, az 1944-ben kiadott oktatási törvényt (Secondary School for All) illeti, csupán az erős állami központi tanügyigazgatás kiépítésében emlékeztet a kelet európai oktatási reformokra, meg abban is, hogy a törvényt forradalmi tettnek nevezték Munkás Párti kezdeményezői. De abban már nem hasonlít a szovjetek iniciálta modellre hiszen a törvény végrehajtását az elfogadás követően három évvel később, 1947-48-ban kezdték meg. Még abban is különbözik, hogy az új iskolarendszerbe szeletív elemeket (a Grammar shcool-ok teszten alapuló felvételijéhez illesztett a 11 éves kori vizsga, amely alapján a tanulóknak kb. 8 \%-át vették fel, a többség (70\%) a modern school-ban tanulhatott tovább), valamint a magániskolák rendszerét tudatosan építettek be, amelyek következtében az alsó középfokú képzés nem szólt mindenkinek, ám a politikai marketing egy ideig hatott. Csupán 1965 került sor Munkáspárti kezdeményezésre a középfokú oktatás egységesítésére, az állami komprehenzív iskolák formájában, amelyet öt év múlva a konzervatív párt olyképpen jelentéktelenített el, hogy az iskolák indítását, a képzési forma megválasztását és az iskola fenntartását helyi szintre helyezte (Bernstein, 1959; Stamford, 1967; Ujcz, 1971).

\footnotetext{
${ }^{22}$ A társadalmi egyenlőség - amit sokan szúken a demokráciával azonosítanak - megteremtésének első szocialista lépését a keleti német demokratikus kommunista párt tette meg az 1946 -os törvényben: a gimnázium (high school) szociális összetételét kezdetben az iskolakörzettel arányosan szabta meg. A fiúk és a lányok, illetve később a munkás és paraszt származásúaknak az arányának az 50 \%-ot kellett meghaladnia (Hofman, 1962. 49. o.).
} 
Az amerikai csapatok által felszabadított Olaszországban sem változott meg a zsákutcás oktatási rendszer szerkezete 1962-ig. Lényegében megmaradt Gentile 1929-ben javasolta erősen szelektív oktatási rendszer 1948-as reform után is, a szelekciós pont a 10. életévnél továbbra is fennmaradt. ${ }^{23}$ ) Az oktatásirányítás magas fokú centralizáltsága is Mussolini öröksége, s a katolikus egyház befolyása a Kereszténydemokrata Párton keresztül továbbra is jelentôsen érvényesült (Grimaldi és Serpieri, 2012).

Ausztriában és Bécsben az amerikai, angol, francia, valamint szovjet megszállási övezetre osztott hatalmi egyensúly megakadályozta az iskola szerkezet átalakítását is. Az 1955-ben függetlenné és semlegessé vált országban konzerválódott a háború előtti oktatási rendszer az 1962-es reformig: a négy osztályos elemi iskolára épült a nyolc osztályos gimnázium és a négyosztályos szakképzés, illetve a munkaerőpiac felé terelő ág, amelybe a tanulók 90\%-a járt. A katolikus egyház megközelítőleg az iskolák tíz százalékát tartotta fenn ekkor. Ausztriában sohasem volt kizárólagos a szovjet politikai befolyás, nem is tartozott a Szovjetunió közvetlen irányítása alá olyképpen, mint a többi kelet európai országban, ide értve Kelet Németországot. Annak ellenére, hogy 1945-ben a moszkvai számúzetésből hazatérő kommunisták által vezetett Osztrák Kommunista Párt (ÖKP) adta az ideiglenes kormányban az oktatási minisztert, a belügy mellett, de csak novemberig, amikor az első szabad választáson az ÖKP csupán 5\%-ot ért el. Miután meghiúsult az egyesülés a másik baloldali, a Szociáldemokrata párttal (SPÖ), ezzel az oktatáspolitika formálásának a lehetősége a konzervatívabb politikai erők előtt nyílott meg (Beer, 2007). Ausztria és oktatási rendszere a nyugat európai úton indult el.

Egy olyan nyugat európai országot sem ismerünk, amelyikben az alsó középiskola rovására növelték volna a népoktatást, amelyikben az egységes alapoktatást 14 éves korig emelték volna, mint például Magyarországon, vagy a hasonló politikát folytató, szovjet befolyás alatt álló országokban.

\section{A KELET- ÉS NYUGAT-EURÓPAI ÚT KÜLÖNBSÉGE}

A háború utáni egységesség jegyeit mutató kelet és a differenciált nyugat európai oktatási-rendszer politika közötti alapvető különbség arra utal, hogy a keleti rész egységességét a határokon átnyúló koordináció teremtette meg, míg a nyugati sokszínúséget pedig éppen ennek a hiánya magyarázza. KeletEurópában az egységes és általános alapfokú oktatás megteremtése alapvetően politikai taktika eredménye, politikai termék, távolról sem pedagógiai, szakmai logika következménye. ${ }^{24}$

\footnotetext{
${ }^{23}$ Az alsó fokú oktatás 6-10, az alsó középfokú 11-13 és a felső középfokú képzés 13-18 évig tartott (Grimaldi, Emiliano-Serpieri és Roberto (2012).

24 A politikai konszolidáció terméke, hogy általános emlékezetben csak az eszközként használt pedagógiai szempontok maradtak meg, az a látszatot keltve, mintha ez lett volna az elsődleges. A születés aktusa és körülményei, előzményei - a 8 osztályos népiskola megteremtése 1940-ben, s a
} 
Természetesen nem arról van szó, a kommunista, vagy a szociáldemokrata pártok, vagy a baloldali gondolkodású értelmiségiek nem szerettek volna a munkások és a parasztok emancipációját támogatandó számukra hosszabb képzést nyújtó iskolarendszert kiépíteni, ami persze alapvetően más, mint a népiskola szelekciós pontját 10 éves korban meghagyó felső tagozat indítása. A háború előtt tartós kormányzati helyzetbe a társadalmi egyelőséget szorgalmazó képviselők sohasem kerültek (Kozma, 1972. 13. o.). A háború utáni terveikből, mint például a két francia kommunista identitású és párttagságú tudósok nevét viselő bizottsági munkából, a Langevin ${ }^{25}$-Wallon ${ }^{26}$ koncepcióból ${ }^{27}$ - semmi sem lett. A fentebb már említett UNESCO hamburgi konferencia megállapította 1956ban, hogy „az iskolarendszer szerkezete egy fél évszázada lényegében nem módosult”

tankötelezettség felemelése 14 évre - többnyire homályban szoktak maradni, ami esetünkben az is indokolja, hogy 1950 utáni években a pedagógiai elit politikai függőségét szakmai kizárólagosság logikával fedte le.

${ }^{25}$ Paul Langevin (1882-1946), jelentős fizikus, a Langevin dinamit és a tengeralattjáró detektor, a Sonar feltalálója. Alapítója 1934-ben a Comité de vigilance des intellectuels antifascistes. A Francia Kommunista Pártnak tagjaként elnöke Human Rights League (LDH) 1944 és 1946 között. A Vichy kormány alatt háziőrizetben volt. A Pantheonban temették le. A forrás nem említi oktatáspolitikai töménységet.

26 Henri Paul Hyacinthe Wallon (1879-1962), filozófus, szociál-pszichológus, fejlődéslélektan kutatója, ideggyógyász tanár és politikus. Meggyőzéses marxistaként politizált, s e mellett fejlődéslélektan területén végzett kutatásokat. (ld. Psychology and Dialectical Materialism, (1942), vagy Makarenko, le Chemin de la vie (1950) (Makarenko, az élet útja c. munkáját). Wallon 1931-ben csatlakozott a francia szocialista párthoz (SFIO) majd tagja lett a francia kommunista pártnak (PCF) 1942-ben. 1944-ben, a felszabadulás után vezető szerepet kapott oktatásügy államigazgatásában. 1945 és 1946 között választott kommunista képviselőként, elnökként részt vett az oktatási reformot kidolgozó bizottságban, mely az Oktatásügyi Minisztérium égisze alatt múködött. A reform a Langevin-Wallon Project néven vált ismertté (1945).

27 A tervezet lényeges politikai célja, hogy a "hivatali tevékenységek megoszlását többé ne a vagyon vagy a társadalmi osztály szabja meg, hanem a hivatás betöltésére való alkalmasság" (Ágoston, 1966. 8. o.). Tehát megszüntetendő, hogy „az egyes iskolafajták összetételét ma gyakran a szülők társadalmi osztálya és jövedelme határozza meg (Ágoston, 1966. 20. o.). A fizikai munka emancipálása a további cél: "A kézi tevékenységek, a gyakorlati intelligencia, a technikai kiválóság magas anyagi és erkölcsi értékének az elismerését követeli meg."(Ágoston, 1966. 18. o.). Az oktatási rendszer szervező elve a tanulók tanulói "fejlettségi szinteknek, majd speciális képességeknek feleljenek meg, ne pedig társadalmi kategóriáknak" (Ágoston, 1966. 20. o.). A társadalom részben pszichológiai elvú elrendezését és szervezését és a "társadalmi feladatok jobb szétosztását" hirdeti a tervezet, amely „egyszerre szolgálja a közösségi érdeket és az egyéni boldogságot" (Ágoston, 1966. 18. o.). Ennek érdekében a 7 évtől kezdődő tankötelezettséget felső határát felemelték 14-ről 18-ra s a képzési időt három szakaszra - 7-11, 11-15 és 15-18 évesekre képzésére bontották. A szakmai orientációs képzés a 15 évvel kezdődik, s majd egyre bővül, ennek következtében az általánosan képző tárgyak óraszáma csökken. A 15-18 évesek útja három irányba mutat. 1) a korábbi elkülönült szakmunkásképzés helyet gyakorlati tagozat felé vezet, s a tanulót a pályaválasztási tanácsadók felügyelik az első évben. Az általános képzésre nagy súlyt helytettek. 2) szakirányú tagozatra „,azokat a gyermekek, akik a termelés középkáderi lehetnek, és akik több képességet árulnak el a végrehajtás, mint az az elméleti tanulmányok iránt (Ágoston, 1966. 29. o.): És a 3, az elméleti irányba az olyan gyermekeket irányítanak, 'akiknek elméleti tanulmányokra való képességeiket felismerték [a pedagógusok (?) ( S. G.)], akiket érettségi, vagy az azt helyettesítő vizsgákra készítenek elö. (Ágoston, 1966. 29. o. ) A pedagógusképzésben megszűntetnék a tanító és tanárképzés rendszerét, s helyette kétféle, az általános és szakképzést oktatásra alkalmas pedagógusokat bocsátanának ki. A hagyományos, a középosztály értékrendjét követő Líceumi rendszer megszúnne, miképpen Grand Ecole-k önállósága. A tervezet a középosztály érdekei ellen politizál. 
(Faragó, 1959a. 17-18. o.).

Nyugat Európában nem zajlott le az a fordulat, ami Kelet Európában közvetlenül a háború után mindenütt megtörtént, ahol létrehozták az egységes, belső szerkezetében még tagozat mélységéig is ritkán tagolt általános iskolát. Nem a koncepció a szovjet termék, hanem a megvalósult ígéretből fakadó politikai haszon megszerzésének szándéka és technológiája, az 1945-ös novemberi nemzetgyúlési választáson a győzelem elérése, ami nem sikerült. Mindazonáltal számos jel utal arra, hogy a Szovjetunió oktatás politikáját követő nyugat európai kommunista pártok - már, ahol voltak ${ }^{28}$ - ugyanazt a cél követték, mint kelet európai elvtársaik.

A Langevin-Wallon bizottság reformjavaslatait 1947-ben egy magyar szakmai értékelés szerint ,az antidemokratikus erők felülkerekedése akadályozta a reform végrehajtását”(Hegedüs, 1971b. 111. o.) ${ }^{29}$, csupán a "Francia Kommunista Párt harcolt a legkövetkezetesebben a demokratikus oktatási reformért (Hegedüs, 1971b. 111. o.).

A hidegháború egyik fontos csatájában a Sztálini szándékot követő kommunisták és vezetőik, Thorez Franciaországban és Togliatti Olaszországban 1947-ban valóban végképp ${ }^{30}$ távol kerültek a végrehajtó hatalomtól (Brogi, 2011). Ennek következtében, ahogy Ágoston György írja, "a népi erőket kiszorították a hatalomból” (Ágoston, 1966. 10. o.), így hát az „antidemokratikus erők” (Hegedüs, 1971b. 111. o.), értsd a szovjetellenes erők a 6-11 éves korig tartó egységes népiskolai rendszer fenntartása mellett foglaltak állást. ${ }^{31}$

A hatvanas évek közepéből a sztálini oktatáspolitika magyarországi vezéralakjának tollából a hidegháborús hangnemben „A finánctőke gazdasági és politikai hatalmának megszilárdításával a tökésosztály és a kiváltságos rétegek müveltségi monopóliumát igyekezett megerősiteni. A legmerevebben ellene szegült minden olyan törekvésnek, amely a munkások és parasztok gyermekeit tömegesen magasabb végzettséghez kívánta juttatni" (tehát nem több tudáshoz ${ }^{32}$ S.G.) (Ágoston, 1966. 10. o.), amit a kommunisták szerettek volna, de veszítettek. ${ }^{33}$

\footnotetext{
${ }^{28}$ Németországban - a későbbi NSZK területén - a kommunista párt jelentősége elenyészőnek tekinthető Svédországban a szociáldemokraták mellett nem nyílt számottevő tér kommunistáknak. Olaszországban azonban Európa legnagyobb kommunista pártjának oktatási programját - eddig közelebbről nem ismerjük, annyi bizonyosnak tûnik, hogy a jogalkotásban nem értek el sikereket.

${ }^{29}$ Az idézet illusztrálja a hetvenes évek politikai kultúráját vagy nem érti a szerző a többpártrendszerú demokráciák konfliktus kezelési berendezkedését, vagy pedig törzsi szemlélete alapján csak a kommunista politika a demokratikus, s ettől eltérő minden más az antidemokratikus.

30 Togliatti az 1948 áprilisi a hidegháború szellemében szervezett választások után került távol a hatalomtól.

31 A nyugat európai országok többségében formálisan is megmaradt a népiskolák felső tagozata, a „Zsákutca”, a szelekciós pont népiskola alsó tagozata végén maradt. A szelekció helye az alsó tagozat végén maradt, azonban új iskolatípusok épültek rá, amelyek döntően a fizikai munka világába vezették növendékeiket, a furkációs rendszer legvastagabb ágaként.

${ }^{32}$ Még egy apró bizonyíték, hogy nem pedagógiai szempont volt az elsőleges, hanem a politikai, a szelektív bizonyítványhoz kapcsolódó jogok átadásával az elit társadalmi helyzetének elérését ígérték olyképpen, hogy a bizonyítvány megszerzéséhez szükséges munkaterheken csökkentették volna. Voltaképpen a bizonyítvány bizonyító erejének infláltatása volt a cél.

33 Megfigyelhető a pedagógiai nyelvezet ideologikus volta. Koncepciók és ideák összeütközését
} 
Kelet Európában azonban az ,antidemokratikus erők” mindenütt le lettek győzve, Ágoston György szerint „,a szocialista országok [...] közoktatásában a Langevin Wallon-terv már maradék nélkül érvényesülnek" (U. o.). ${ }^{34}$ Azaz a kommunista típusú totális központosítás elől minden akadály elhárult, s szabaddá vált az út a totalitárius berendezkedés felé, amelynek elme a demokratikusnak nevezett az egységes és általános iskolára épülő oktatási rendszer.

\section{A KÖVETKEZTETÉSEK}

Rendkívül ironikusnak tûnik, hogy az általános iskolát a győztes Szovjetunió politikai érdeke szerint hozta létre a kommunista párt Magyarországon és a Szovjetunió széthullásával együtt szúnik meg az egységes képzési tartalmú, mindenki számára egyaránt kötelező 8 osztályos átalános iskola. A 6 és a 8 osztályos gimnáziumok létrejöttével megszúnt a szerkezeti egységesség, emellett az iskolánkként a tantestületek által szabadon választott pedagógiai programok rendszere felszámolta a mindenki számára elérhető alapmúveltséghez köthető társadalmi egyenlőség intézményes hátterét.

Végtelenül ironikus, hogy kezdet és a vég egyaránt baloldali ideológián alapult. A korábbi neveléstudomány és a pszichológia szempontjait követő erôs államtól, a központi irányitás szakszerúségétől várta a kulturális egyenlőség eljövetelét, a másik pedig az önszerveződő iskolától remélte ugyanezt (Sáska, 2002, 2003). Paradox módon az iskolák szakmai autonómiája nem a remélt társadalmi egyenlőséget hozta el, hanem a tantestületek és a tudatos iskolaválasztó érdekei valósultak meg. Noha ez a pedagógiai programok hallatlan színességét teremtette meg, de ezzel együtt a példátlanul erős kulturális gyökerú társadalmi

a jó és a rossz küzdelmeként értékelik, s ez a normatív megközelítés a vallásháborúk logikájára emlékeztet. Ez a fajta gondolkodásmód nem tekinthető tudományosnak, hiszen nem a küzdő felek konfliktusait, hanem ideológiájuk különbözőségét írja le az agitációs célzattal.

${ }^{34}$ Az állításban annyi igazolható, hogy valóban érvényesült az egyenlőséget teremtő középosztályellenes politika, s a munkás és paraszt származásúak közül többen kaptak magasabb végzettséget. Amúgy erős túlzás, szinte valótlanságot, vagy inkább politikai elfogultságot tükröznek Ágoston szavai. A szocialista országokban az oktatási rendszerek egységesebbek voltak az ötvenes években, azaz a formális szociális egyenlőséget hatékonyabban kényszerítették ki, annak ellenére, hogy a tankötelezettség felső határa alacsonyabb volt a Lagevin-Wallon tervezethez képest. A francia koncepció 13-14 éves kor után teszi az iskolán belüli formális szelekció első megjelenését, amely előkészíti a diákokat arra, hogy a 15. évben - lélektani alkatukhoz legjobban illeszkedően, vagy a négy évig tartó elméleti tagozaton (irodalmi, természettudományi, technikai ágazatban), vagy pedig a szakirányú képzésben, illetve gyakorlati tagozaton, azaz a szakmunkásképzésben folytassák tanulmányaikat. Magyarországon az általános iskola felső tagozatának legelső óraterveiben voltak választható tárgyak, a felső tagozaton, de ez az opciót elvetették, a képzés totálisan egységes lett. Kovács Máté 1945-ben készült javaslata szerint heti hat órában a felső tagozaton „élő idegen nyelv, klasszikus idegen nyelv, esetleg zene, technikai-mechanikai nevelést, vagy végül a gyakorlati termelés fogásaira ránevelo" mezögazdasági és kertészeti gyakorlatok számára kell fenntartani. [...] E szabad foglalkozások nem kötelező rendes tárgyaknak tekintendők" (Kovács, 1983. 194. o.). A Langevin-Wallon tervezet a pedagógus hivatás megbecsülését és anyagi elismerését túzte ki célul, valamint "A tanitóknak és tanároknak meglegyen [...] erkölcsi és anyagi függetlenségük” (Ágoston, 1966. 22. o.). Az egypárti rendszerú népi demokráciákban totális politikai függésbe kerültek a pedagógusok. 
szelekciót is létrehozta (Berényi Berkovits és Erőss, 2008). Az iskolarendszer szelekciós pontja lejjebb került, amit nehéz lenne az oktatási rendszer immanens tulajdonságaival magyarázni.

Be kell látni, hogy a sikeres baloldali kísérletek - mint a komprehenzív iskolák, vagy a finn/svéd modell csupán a polgári demokratikus úton haladó Nyugat-Európában alakultak ki bő negyedszázad alatt, ott is csak a szabadon választott baloldali kormányok alatt, amelyek intézkedéseit a más érdekeket képviselő politikai alakulatok idővel korrigáltak. A nyugat európai komprehenzív iskolák bő tíz évvel később nyíltak meg, mint a hasonló célokat követő kelet-európai alsófokú intézmények..

Mindez persze nem azt jelenti, hogy szovjet rendszerú szocializmusban ne lettek volna olyan (nevelés)tudósok, és politikusok, akik a teljes társadalmi egyenlőséget és a gazdasági jólétet így vagy úgy, de megteremthetőnek vélték a magát kizsákmányolás nélküli, az emberek mindenoldalú kibontakozását lehetővé tekintő politikai rendszerben, azonban tévedtek, mint sokan mások. A szocialista államok közössége és állami pedagógiája nem bizonyult sem életképesnek sem magasabb rendúnek a nyugat-európai kapitalista országokhoz képest. Ez a tény a múlt részének megkerülhetetlen és visszahozhatatlan elemének kellene tekinteni. ${ }^{35}$

\section{FELHASZNÁLT IRODALOM}

Ábent Ferenc és mtsai (1965): A Magyar Népköztársaság közoktatásügye. In: Ábent Ferenc (szerk.): A közoktatásügy Európa szocialista országaiban. Tankönyvkiadó, Budapest.

Ágoston György (1966): Előszó. Bevezető tanulmány. In: Ágoston György (ford.): A Langevin-Wallon tervezet. Tankönyvkiadó, Budapest.

Akerman, Oscar (1967): Svédország. In: Illés Lajosné (1967, szerk.): Nyolc tőkésállam közoktatási rendszere. Tankönvykiadó Budapest.

Applebaum, Anne (2012): Iron Cutrain. The Crusing of Eastern Europe 19441956. McClelland and Stewart, Toronto.

Arendt, Hannah (1992): A totalitarizmus gyökerei. Európa Könyvkiadó, Budapest.

Arszenyev, A. M. (1965): A szocialista és kommunista nevelés alapvonásai. In: Ábent Ferenc (szerk.): A közoktatásügy Európa szocialista országaiban.

Bassola Zoltán (1998): Ki voltam. . . Egy kultuszminisztériumi államtitkár vallomásai. Országos Pedagógiai Könyvtár és Múzeum, Budapest.

Beer, Siegfried (2007) The Soviet occupation of Austria, 1945-1955 Recent research and perspectives. Letöltés: http://www.eurozine.com/the-soviet-occupation -of-austria-1945-1955/, 2017. december 7. 20:20.

\footnotetext{
${ }^{35}$ Köszönöm Laki Mihály fontos észrevételeit és tanácsait.
} 
Bernstein, M. Sz. (1959): Sovány eredmények - az 1944. évi Education act éltebelépésének 10. évfordulójára. In: Faragó László (1959, szerk.): Az iskolareform és a nevelés problémái a kapitalista országokban. Tanulmányok és dokumentumok. Kézirat. Pedagógiai Tudományos Intézet, Budapest. 117-178.

Boda István (1944): A magyar lélek alapformái és természetes fejlődéslehetôségei. In: Kiss Árpád és Kovács Máté (szerk.): Magyarságtudomány és nemzetnevelés. Nagy Károly grafikai múintézete, Debrecen. 21-45. Letöltés: http: //mtdaportal.extra.hu/books/magyarsagtudomany_es_nemzetneveles.pdf, 2016.04.09. 10:39.

Brogi, Alessandro (2011): Confronting America: The Cold War Between the United States and the Communists in France and Italy. University of North Carolina Press Chapel Hill.

Csakarov, Najden, és mtsai (1965): A Bolgár Népköztársaság közoktatásügye. In: Ábent Ferenc (szerk.): A közoktatásügy Európa szocialista országaiban. Tankönyvkiadó, Budapest. 47-110.

Danics Istvánné. (1979, szerk.): Dokumentumok a magyar közoktatás reformjáról, 1945-1948. Kossuth Könyvkiadó, Budapest.

Dévényi Anna (2012): A nemzetnevelés szerepe Gömbös Gyula és Hóman Bálint politikájában. Képzés és Gyakorlat, 10. 3-4. sz. 22-35.

Donáth Péter (2008): Oktatáspolitika és tanitóképzés Magyarországon 1945-1960. Trezor Kiadó, Budapest.

Donáth Péter (2015): Tanítói, tanári viták. A magyarországi tanítók társadalmi küldetéséről, helyzetük javításáról, a tanítóképzés korszerúsítéséről, felsőfokúvá tételéről 1890-1905. In: Donáth Péter (szerk.): Filozófia-múvelődés - történet. A Budapesti Tanítóképző Főiskola Tudományos Közleményei címú kiadványsorozat folytatása. 256-259.

Dyma, Mojmír és Kozjar, Jaroslav (1965): A Csehszlovák Szocialista Köztársaság közoktatásügye. In: Ábent Ferenc (szerk.): A közoktatásügy Európa szocialista országaiban. Tankönyvkiadó, Budapest. 111-182.

Eckhardt Sándor (1941, szerk.): Úr és paraszt a magyar élet egységében. Budapesti Kir. Magyar Pázmány Péter Tudományegyetem Bölcsészeti Karának Magyarságtudományi Intézete, Budapest Letöltés: http://mtdaportal . extra .hu/books/eckhardt_sandor_ur_es_paraszt.pdf, 2016.04.09.

Faragó László és Kiss Árpád (1949): Az új nevelés kérdései. Egyetemi Nyomda, Budapest.

Erőss Gábor (2008): Iskolarend - Kiváltság és különbségtétel a közoktatásban. Gondolat Kiadói Kör, Budapest.

Faragó László (1959a, szerk.): Az iskolareform és a nevelés problémái a kapitalista országokban. Pedagógiai Tudományos Intézet, Budapest.

Faragó László (1959b. szerk.): A nevelés és iskolarendszer problémái néhány szocialista országban. Pedagógiai Tudományos Intézet, Budapest.

Georgeoff, Peter, John (1977): The Educational System of Bulgaria Education around the World Office of Education (TEEN). Washington. Leöltés: http://eric 
.ed.gov/?id=ED156600], 2016.04.09.

Glen, Cherles. L. (1995): Educational Freedom in Eastern Europen. Cato Intitue, Washington DC

Grimaldi, Emiliano and Serpieri, Roberto (2012): The transformation of the Education State in Italy: a critical policy historiography from 1944 to 2011. Italian Journal Of Sociology of Education, 4. 1. sz. 146-180.

Gross, Jan, Thomas (2002): Neighbors. The Destruction of the Jewish Community in Jedwabne, Poland. Princeton University Press, New Jersey.

Hegedûs Lászlóné (1971a): Svédország In: Hegedûs Lászlóné (szerk.): Iskolarendszerek és fejlesztési tendenciák. Országos Pedagógiai Könyvtár és Múzeum, Budapest. 146-162.

Hegedûs Lászlóné (1971b): Német Szövetségi Köztársaság. In: Hegedûs Lászlóné (szerk.): Iskolarendszerek és fejlesztési tendenciák. Országos Pedagógiai Könyvtár és Múzeum, Budapest. 127-145.

Hilker Franz (1959): A pedagógiai helyzet a Német Szövetségi Köztársaságban. In: Faragó László (1959, szerk.): Az iskolareform és a nevelés problémái a kapitalista országokban. Tanulmányok és dokumentumok. Kézirat. Pedagógiai Tudományos Intézet, Budapest. 101-117.

Hofmann, Erich (1962): The Changing School in East German. Comparative Education Review, 6. 1. sz. 48-57

Horváth Márton (1978): Közoktatás-politika és általános iskola. Akadémiai Kiadó, Budapest.

Husén, Tortsten und Bolt, George (1964): Bildungsforschung und Schulreform in Sweden. Klett, Stuttgart.

Jóború Magda (1962): Élet és iskola. A modern köznevelés történelmi és társadalmi háttere. Gondolat kiadó, Budapest.

Jóború Magda (1963): A középiskola szerepe a Horthy-korszak müvelődéspolitikájában. Tankönyvkiadó, Budapest.

Jóború Magda (1972): A köznevelés a Horthy-korszakban. Kossuth Könyvkiadó - Tankönyvkiadó, Budapest.

Hobsbawm, Erik (1998): A szélsőségek kora. A rövid 20. század története 19141991. Panninica Kiadó, Budapest.

Kalmár Melinda (2014): Történelmi galaxisok vonzásában Magyarország és a Szovjetrendszer 1945-1990. Osiris Kiadó, Budapest.

Kardos József (2007): Iskola a politika sodrásában 1945-1993. Gondolat-Infonia Kiadó, Budapest.

Kaszvin, G.A. és Sibanov, A. A. (1959): A Csehszlovák Köztársaság iskolareformjáról. In: Faragó László (szerk.): A nevelés és az iskolarendszer problémái néhány szocialista országban. Dokumentumok és tanulmányok. Pedagógiai Tudományos Intéztet, Budapest. 140-139. Kézirat.

Kaszvin, G. A. (1959): Bolgár Népköztársaság. In: Faragó László szerk.: A nevelés és az iskolarendszer problémái néhány szocialista országban. Dokumentumok és tanulmányok. Kézirat. Pedagógiai Tudományos Intéztet, Budapest. 139-140. 
Kelemen Elemér (1993): A magyar pedagógusmozgalmak és -szakszervezetek vázlatos története. In: Tomori Lajos (szerk.): „Lázad hát már az élet alágyürtje, a tanító...?" 75 éves a Pedagógusok Szakszervezete. Pedagógusok Szakszervezete, [H. n.é.]. 7-48.

Kerepeszki Róbert (2004): A Debreceni Egyetem Bölcsészettudományi Karának története, 1912-1949. In: Papp Klára (szerk.): A Debreceni Egyetem Bölcsészettudományi Karának története. Debreceni Egyetem, Debrecen.

Kiss Árpád (1946): A tankönyv. Köznevelés, 1. 22. sz. 1-3.

Kiss Árpád (1947): Az általános iskola és középiskola. Köznevelés, 2. 6. sz. 102-106.

Kornidesz Mihály és Kurucz Imre (1966): Az iskolareform a megvalósulás útján. Kossuth, Budapest.

Kovács Máté (1983): A magyar köznevelés korszerû kifejlesztése. In: Szelle Béla (szerk.): Kovács Máté emlékkönyv. Magyar Könyvtárosok Egyesülete, Budapest. 175-216.

Kozma Tamás (1972): Torsten Husén és a svéd neveléstudomány. In: Kozma Tamás (szerk): Torsten Husén: Iskola az ezredfordulón. Válogatott tanulmányok. Tankönyvkiadó, Budapest.

Ladányi Andor (1989): Mennyiségi fejlődés és strukturális változások: a felsőoktatás útja a felszabadulás után. Tankönyvkiadó - Oktatáskutató Intézet, Budapest.

Mueller, Wolfgang (2006): Soviet Plans and Policies for Austria's Transition to Socialism, 1945-1955.Contemporary Austrian Studies 14. 343-352 p..

Nagy Mária [én]: X-esek. Letöltés: http://telepesek.hu/pdf/muhely_X-e s.pdf, 2017.10.30.

Nemes Dezső (1960): Magyarország felszabadulása. Kossuth Könyvkiadó, Budapest.

Pecherski, Mieczyslaw (1965): A Lengyel Népköztársaság közoktatásügye. In: Ábent Ferenc (szerk.): A közoktatásügy Európa szocialista országaiban. Tankönyvkiadó, Budapest. 183-256.

Péter Ernő (1971): Az V. Nevelésügyi Kongresszus feladata és módszerei. In: Kiss Árpád (szerk.): Ötödik nevelésügyi Kongresszus. I. kötet. Budapest. 15-34.

Pukánszky Béla és Németh András (1996): Neveléstörténet. Nemzeti Tankönyvkiadó Rt., Budapest. Letöltés: http://mek.oszk.hu/01800/01893/html /index.htm, 2017.12.07.

Rainer M. János és Lux Zoltán (2000, szerk.): Demokratikus újrakezdési kísérlet, 1944-1946. In: Magyarország története, 1944-1953 - digitális történeti segédkönyv. Az 1956-os Magyar Forradalom Történetének Dokumentációs és Kutatóintézete Közalapítvány, Budapest. [URL: http://www.rev.hu/sulinet 45/ora1/index.htm] Letöltési idő: 2017. november 27.

Sáska Géza (1981): Egy döntéssorozat kényszerpályája. Mozgó Világ, 7. 12. sz. 116-124.

Sáska Géza (1992): Ciklikusság és centralizáció. A központosítot tanügyigazgatás és a felnőtoktatás esete. Educatio, Budapest. 
Sáska Géza (2001): Összevetés: A közmúveltség kiterjedtsége, a szakmai autonómia foka, a társadalmi egyenlőség kívánatos mértéke és hatása az iskola szervezetére 1945-ben és 1985-ben. Új Pedagógiai Szemle, 51. 6 sz. 33-47.

Sáska Géza (2002-2003): The Age of Autonomy. European Education, 34. 4. 34-56.

Sáska Géza (2006): A társadalmi egyenlőség megteremtésének kísérlete az ötvenes évek felsőoktatásában. Educatio, 15. 3. sz. 593-608.

Sáska Géza (2016): Az oktatási rendszer reformja a negyvenes években és a kommunista identitáspolitika, In: Németh András, Garai Imre és Szabó Zoltán András (szerk.): Neveléstudomány és pedagógiai kommunikáció a szocializmus időszakában. Gondolat Kiadó, Budapest. 235-284.

Skubić, Emerenc, Klara- Spasenović, Vera- Vuisić-Živković, Natasa, - Vrcelj, Popov, Nicolay (2013):Comparative Pedagogy in Slavonic South East European Countries. In: Wiseman, W. Alexander, Emily Anderson (szerk.): Annual Review of Comaparative and International Education International Perspectives on Education and Society. 191-220.

Simon Gyula (1965, szerk.) Előszó. Nevelésügyünk húsz éve 1945-1964. Tankönyvkiadó, Budapest.

Simon Gyula (1970): Felszabadult nevelésügyünk huszonöt évérről. Pedagógiai Szemle, 20. 4. sz. 317-325. Újraközli Horváth Márton és Zibolen Endre (1975, szerk.): 30 év neveléstudomány és müvelődéspolitika. Magyar Pedagógiai Társasság, Budapest.

Szabó Miklós (2014): A jó kommunista együtt ingadozik a párttal 19832003. In: Jankó Attila (szerk.): Elöadások a kommunista pártok történetéről és a fekete-piros-fehér-zöld szinre festett sztálinizmusról. JATE PRESS, Szeged.

Szabolcs Éva (2006, szerk.): Pedagógia és politika a XX. század második felében Magyarországon. Eötvös József Kiadó, Budapest.

Stamford, N. C.: Az Egyesült Királyság. In: Illés Lajosné (1967, szerk.): Nyolc tőkésállam közoktatási rendszere. Tankönyvkiadó, Budapest.

Stoian, S. Stanciu és Gabrea, Iosif (1965): A Román Népköztársaság közoktatásügye. In: Ábent Ferenc (szerk.): A közoktatásügy Európa szocialista országaiban. Tankönyvkiadó, Budapest. 399-460.

Tarján M. Tamás (2017): 1945. február 4. Megkezdődik a jaltai konferencia. Letöltés: http://www.rubicon.hu/magyar/oldalak/1945_februar_4_megkezd odik_a_jaltai_konferencia, 2017.12.02.

Ujcz Pálné (1971): Anglia. In: Hegedûs Lászlóné (szerk.): Iskolarendszerek és fejlesztési tendenciák. Országos Pedagógiai Könyvtár és Múzeum, Budapest, 94-109. 